\title{
Fiscal Decentralization and Redistribution: Considering Inclusive Growth
}

\author{
Kim Aejin ${ }^{1}$, Kim Jina ${ }^{2}$ and Park Jhungsoo ${ }^{3^{*}}$ \\ ${ }^{1}$ Professor of Public administration, Gyeongsang University, Jinju, Republic of \\ Korea \\ ${ }^{2}$ Doctoral Student at Department of Public administration, Ewha Womans \\ University, Seoul, Republic of Korea \\ 3* Professor of Public policy, Ewha Womans University, Seoul, Republic of Korea \\ 1jins@gnu.ac.kr, ${ }^{2}$ ja85@ewhain.net, ${ }^{3}$ parkj@ewha.ac.kr
}

\begin{abstract}
The importance of inclusive growth, which includes both economic growth and mitigation of inequality, is being discussed in many countries. Notably, some studies have actively shown the relationship between fiscal decentralization and income redistribution based on the decentralization theorem that fiscal decentralization affects the competitiveness of the economy and the performance of government. This paper empirically analyzed the effect of fiscal decentralization on inclusive growth focused on income redistribution. The analysis showed that fiscal decentralization had a statistically significant impact on inclusive growth, particularly on redistribution indicators such as the Gini coefficient level, labor income share. As a result, fiscal decentralization, which transfers not only financial resources but decisionmaking authority to local governments, can contribute to reducing inequality by increasing the level of welfare for the people.
\end{abstract}

Keywords: Fiscal decentralization, Inclusive growth, Redistribution, Laffer curve

\section{Introduction}

Recently, international organizations such as the World Bank, IMF, OECD approach the relationship between economic growth and inequality from a new perspective and suggest 'inclusive growth' as a solution. Inclusive growth is a concept that comprehensively pursues economic growth and mitigation of inequality, and until recently has focused on the study between individuals' income redistribution and economic growth [1][2][3][4]. However, there may be gaps in income between regions within a country, such as the financial conflict between northern and southern Italy, the claim of independence in Spain's Catalonia region, and inequality among Seoul metropolitan areas and other regions in South Korea. Thus, some studies analyzed the relationship between fiscal decentralization and inclusive growth policies in terms of income redistribution [5][6][7][8][9][10].

The problem is that there is a need for further discussion on how this fiscal decentralization affects not only the regional gap but also the social welfare level of residents, and in particular, the inclusive growth, such as income redistribution. Based on the discussion of previous studies,

Article history:

Received (December 21, 2019), Review Result (January 26, 2020), Accepted (April 5, 2020) 
this study aims to show the effects of fiscal decentralization policy on achieving inclusive growth based on income redistribution.

\section{Relations between fiscal decentralization and redistribution}

Most of the early researches on fiscal decentralization and income redistribution focused on examining the relationship between fiscal decentralization and economic development or economic growth [11][12][13][14][15][16][17]. Recently, however, the concept of inclusive growth has been proposed in terms of easing inequality through income redistribution, and some studies have empirically analyzed the relationship between fiscal decentralization and income inequality directly [5][7][8][10]. These empirical studies suggest different results according to the research model and methodology, such as the target countries of analysis, data covering time period, and variables.

First, research shows that fiscal decentralization contributes to regional economic development and the provision of social infrastructure, thereby consequently alleviates income inequality [10]. These findings explain the decentralization theorem that local governments improve the efficiency of public service provision [18]. On the other hand, research has also shown that fiscal decentralization negatively affects income distribution and can deepen inequality [8][9]. These findings support the classical fiscal federalism theory that the central government can more effectively implement and redistribute income and macroeconomic stabilization policies than local governments [19].

There is also research showing that decentralization affects economic inequalities, depending on the income level of the country. Some studies have shown that decentralization contributes to the reduction of inequality in high-income countries, while it intensifies inequality in low and middle-income countries [5][7]. Income inequality can also be alleviated until the size of the public sector reaches a certain threshold (20\% of GDP), but the larger the public sector, the less effective it is to ease income inequality [9]. There is also research showing that the welfare and income distribution levels of residents improved when the fiscal authority of local governments remains at an appropriate level through the Laffer curve [20]. Eventually, the relationship between fiscal decentralization and income redistribution may differ depending on the quality of the government's fiscal system and financial structure.

\section{Empirical set-up and data}

\subsection{Econometric procedure}

This study conducted an empirical analysis of panel data collected from OECD countries from 1995 to 2017 to examine the long-term relationship between fiscal decentralization and inclusive growth. Based on the previous studies, this study hypothesizes that fiscal decentralization would contribute to inclusive growth up to a certain level, and it will start to fall once it exceeds a certain internal threshold [20]. Thus, it is necessary to check if the relationship is increasing at lower values and decreasing at higher values within the interval. This paper used PCSE (Panel Corrected Standard Error) estimation method and the LindMehlum method of testing $U$ or inverse- $U$ shapes [21] with STATA 14.2. The estimated regression equation is as follows.

$$
Y_{i t}=\alpha+\beta_{1} \text { DREV }_{i t-1}+\beta_{2} D_{T A X}{ }_{i t-1}+\beta_{3} \text { DEXP }_{i t-1}+\beta_{4} E C O_{i t-1}+\beta_{5} \text { POLI }_{i t}+\beta_{6} \text { CIRCUM }_{i t}+\varepsilon_{i t}
$$

$Y$ represents inclusive growth, DREV represents revenue decentralization, DTAX represents tax revenue decentralization, and DEXP represents expenditure decentralization. ECO are 
economic factors that affect inclusive growth, POLI are political and social factors that affect the dependent variable, and CIRCUM are other environmental factors. $\alpha$ and $\beta$ are constants and coefficients, and $\varepsilon$ means random error. i and $t$ represent the country and year, respectively.

\subsection{Measuring key variables}

This study set the Gini gap, labor income share, and the ratio of social welfare expenditure as dependent variables as performance indicators for redistribution policies that measure inclusive growth, considering the importance of easing and fair distributing income inequality. The independent variable of this study is the level of fiscal decentralization, which can be quantitatively measured by surrogate indicators according to OECD guidelines based on previous studies. Lastly, control variables can be divided into economic, political and social, and environmental factors. The contents and sources of data used as dependent, independent, and control variables are shown in [Table1].

Table 1. Definitions and sources of variables

\begin{tabular}{|c|c|c|c|c|}
\hline \multicolumn{3}{|c|}{ Classification } & Definition & Source of data \\
\hline \multirow{3}{*}{$\begin{array}{l}\text { Dependent } \\
\text { variables } \\
\text { (DV) }\end{array}$} & $\begin{array}{l}\text { Individual } \\
\text { income } \\
\text { distribution }\end{array}$ & Gini-gap & $\begin{array}{l}\text { Gini coefficient based on disposable } \\
\text { income after tax and transfer } \\
\text { expenditure (the higher the Gini gap, } \\
\text { the greater the inequality) }\end{array}$ & $\begin{array}{c}\text { OECD Income } \\
\text { Distribution Database }\end{array}$ \\
\hline & $\begin{array}{l}\text { Functional } \\
\text { income } \\
\text { distribution }\end{array}$ & $\begin{array}{l}\text { Labor } \\
\text { income } \\
\text { share }\end{array}$ & $\begin{array}{c}\text { (Employee's remuneration }+ \\
\text { Overseas workers remuneration) / } \\
\text { National Income } * 100\end{array}$ & $\begin{array}{c}\text { OECD Income } \\
\text { Distribution Database }\end{array}$ \\
\hline & $\begin{array}{l}\text { Redistribution } \\
\text { policy }\end{array}$ & $\begin{array}{c}\text { Social } \\
\text { welfare } \\
\text { expenditure }\end{array}$ & $\begin{array}{l}\text { Social welfare expenditure share of } \\
\text { total public expenditure }\end{array}$ & OECD stats \\
\hline \multirow{3}{*}{$\begin{array}{l}\text { Independent } \\
\text { variables } \\
\text { (IV) }\end{array}$} & \multirow{2}{*}{$\begin{array}{c}\text { Revenue } \\
\text { Decentralization }\end{array}$} & DREV & $\begin{array}{l}\text { SREV(Total revenues of local } \\
\text { governments) / GREV(Total } \\
\text { revenues of general governments) }\end{array}$ & $\begin{array}{l}\text { IMF Government } \\
\text { Finance Statistics }\end{array}$ \\
\hline & & DTAX & $\begin{array}{l}\text { STAX (Local tax revenues) / GTAX } \\
\text { (Total tax revenues of general } \\
\text { governments) }\end{array}$ & $\begin{array}{l}\text { IMF Government } \\
\text { Finance Statistics }\end{array}$ \\
\hline & $\begin{array}{c}\text { Expenditure } \\
\text { decentralization }\end{array}$ & DEXP & $\begin{array}{l}\text { SEXP (Total expenditure of local } \\
\text { governments) / GEXP (Total } \\
\text { expenditure of general governments) }\end{array}$ & $\begin{array}{l}\text { IMF Government } \\
\text { Finance Statistics }\end{array}$ \\
\hline \multirow{6}{*}{$\begin{array}{l}\text { Control } \\
\text { variables } \\
(\mathrm{CV})\end{array}$} & \multirow{3}{*}{$\begin{array}{l}\text { Economic } \\
\text { factors }\end{array}$} & $\begin{array}{l}\text { Employment } \\
\text { rate }\end{array}$ & $\begin{array}{l}\text { The proportion of the Employed in } \\
\text { Population 15-65 }\end{array}$ & OECD stats \\
\hline & & $\begin{array}{l}\text { Pre- } \\
\text { intervened } \\
\text { poverty }\end{array}$ & $\begin{array}{l}\text { Percentage of the population whose } \\
\text { income falls below the poverty line } \\
\text { (before taxes) }\end{array}$ & $\begin{array}{c}\text { OECD Income } \\
\text { Distribution Database }\end{array}$ \\
\hline & & $\begin{array}{l}\text { GDP growth } \\
\text { rate }\end{array}$ & GDP growth per year & OECD stats \\
\hline & \multirow{3}{*}{$\begin{array}{l}\text { Politico-social } \\
\text { factors }\end{array}$} & $\begin{array}{c}\text { National } \\
\text { competitive } \\
\text { ness ranking }\end{array}$ & $\begin{array}{c}\text { Global competitiveness report } \\
\text { Ranking }\end{array}$ & $\begin{array}{l}\text { World Economic } \\
\text { Forum }\end{array}$ \\
\hline & & $\begin{array}{l}\text { Government } \\
\text { type }\end{array}$ & $\begin{array}{c}\text { Presidential }=1 \\
\text { Parliamentary system }(\text { president })=2 \\
\text { Parliamentary system }(\text { monarch })=3\end{array}$ & $\begin{array}{l}\text { OECD Government at } \\
\text { a glance }\end{array}$ \\
\hline & & $\begin{array}{l}\text { Local } \\
\text { government } \\
\text { type }\end{array}$ & $\begin{array}{l}\text { State government }=1 \\
\text { Local government }=2\end{array}$ & $\begin{array}{l}\text { IMF Fiscal } \\
\text { Decentralization } \\
\text { Database }\end{array}$ \\
\hline
\end{tabular}




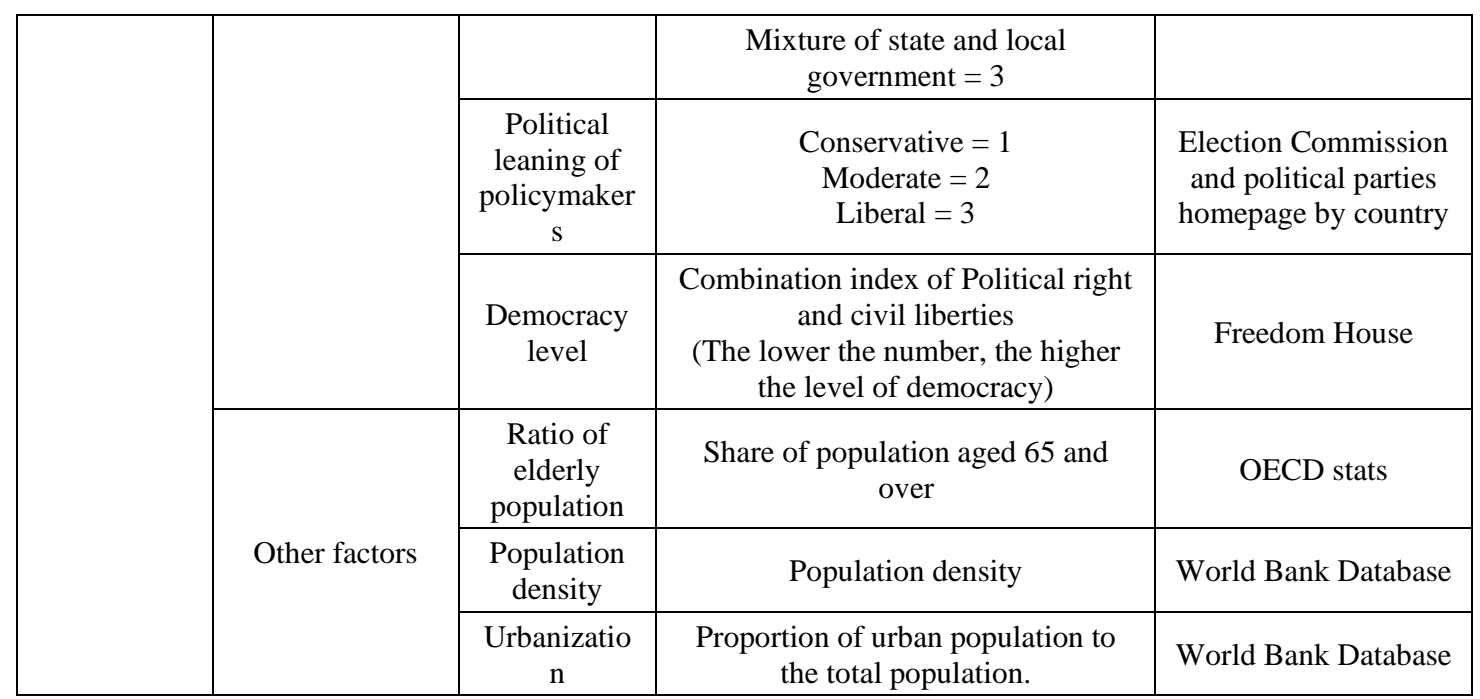

\section{Results}

The results of PCSE analysis are shown in [Table 2]. The tax and expenditure decentralization have negative effects on the Gini Gap. These findings can be understood that the higher the local government's own income, the less inequality in the region. The revenue decentralization, including non-tax revenue, does not have a statistically significant effect on the Gini Gap, but it also has a positive impact on the labor income share. In other words, it can be seen that revenue decentralization contributed to securing jobs for local residents and regional development. The tax decentralization has a positive effect on social welfare expenditure. It can be understood as providing better service jobs and welfare services to residents as the higher the local government's financial strength. The expenditure decentralization has a negative effect on the Gini Gap. However, it is not statistically significant on social welfare expenditure and has a negative on labor income share. This can be understood that local governments need to overhaul the local government's fiscal spending system in a way that can alleviate inequality.

Table 2. PCSE Estimations

\begin{tabular}{|c|c|c|c|c|c|c|}
\hline \multirow{2}{*}{ DV } & \multicolumn{5}{|c|}{ Model 1 } & \multicolumn{3}{c|}{ Model 2} \\
\cline { 2 - 7 } & GINI & LIS & SER & GINI & LIS & SER \\
\hline IV & - & - & - & - & - & - \\
\hline DREV & .0006026 & $.272051 * * *$ & $.227760^{*} * *$ & .001264 & $.2378834 * * *$ & .0352705 \\
\hline DTAX & .0000905 & .0218753 & .0228442 & $-.0005808 * * *$ & .035297 & $.0770871 * * *$ \\
\hline DEXP & $-.001999 * * *$ & $-.226762 * * *$ & $-.174530 * * *$ & $-.0022438 * * *$ & $-.2140297 * * *$ & .0351242 \\
\hline CV & - & - & - & - & - & - \\
\hline
\end{tabular}




\begin{tabular}{|c|c|c|c|c|c|c|}
\hline Employment rate & - & - & - & -.000925 & $.3026568 * * *$ & $-.1560161 * * *$ \\
\hline Pre-tax poverty & - & - & - & -.0733395 & 5.51373 & $33.09568 * * *$ \\
\hline $\begin{array}{l}\text { Ratio of elderly } \\
\text { population }\end{array}$ & - & - & - & -.0000803 & $-.3056084 * * *$ & $.1739246 * * *$ \\
\hline GDP growth rate & - & - & - & -.0000563 & $-.1938236^{* * * *}$ & $-.1347745 * * *$ \\
\hline Government type & - & - & - & $-.0407844 * * *$ & $-3.708263 * * *$ & $3.001156^{* * *}$ \\
\hline Local government type & - & - & - & -.0093122 & $3.154538 * * *$ & .6409648 \\
\hline $\begin{array}{l}\text { Political leaning of } \\
\text { policymaker }\end{array}$ & - & - & - & -.0016562 & .1156118 & .0175905 \\
\hline Democracy level & - & - & - & .005378 & -.2534894 & $-.7470204 * * *$ \\
\hline $\begin{array}{c}\text { National } \\
\text { Competitiveness level }\end{array}$ & - & - & - & -.0002166 & -.0117523 & -.0031235 \\
\hline Population density & - & - & - & $-.0000558 * * *$ & $.0224611 * * *$ & .0002714 \\
\hline Urbanization level & - & - & - & $.0021492 * * *$ & $.110518 * *$ & -.0465184 \\
\hline $\mathrm{R}^{2}$ & 0.9097 & 0.7819 & 0.5209 & 0.9327 & 0.9662 & 0.8307 \\
\hline $\mathrm{N}$ & 420 & 723 & 729 & 336 & 371 & 380 \\
\hline N(group) & 34 & 34 & 34 & 34 & 33 & 34 \\
\hline
\end{tabular}

${ }^{*} p<0.1,{ }^{* *} p<0.05, * * * p<0.01$.

The relationship between the redistribution and the fiscal decentralization index shows that up to a certain level, the higher the level of revenue and tax decentralization, the lower the Gini coefficient, thereby resolving inequality. The fiscal decentralization also has a reverse Ushaped relationship with the labor income share, which shown in [Figure 1]. The expansion of revenue and expenditure decentralization contributes to the improvement of labor income share up to a certain threshold, but if it goes beyond a certain level, it appears to be a factor that will worsen the labor income share. Unlike the Gini coefficient and the labor income share, which were found to have a $U$ or reverse-U-type relationship with fiscal decentralization based on statistical verification, the social welfare expenditures showed different types of results. It is seen as a result of applying a complex hypothesis to identify certain types of non-linearity [21], unlike the traditional method of checking general forms of non-linearity, including quadratic terms within a typical regression equation.

\section{Conclusion}

The analysis showed that tax decentralization has the most positive impact on inclusive growth. Tax decentralization works in a way that improves the Gini coefficient and affects the 
proportion of social welfare spending in a positive direction, which can be seen as contributing to inclusive growth. The revenue decentralization had a positive effect on the labor income share, but it had no statistically significant effect on the Gini coefficient and social welfare expenditure. The expenditure decentralization also had a negative effect on the Gini Gap, but it does have a negative effect on the labor income share. These contradicted expectations could be explained by the impact of the non-tax revenue for boosting the social overhead capital projects those are capital intensive or spending not directly for exclusive residents. Lastly, economic factors among the control variables such as employment rate, pre-intervened poverty rate, elderly population rate, and GDP growth rate had significant effects on inclusive growth. Meanwhile, the type of central government, the population density, and urbanization level among political and environmental factors showed statistically significant results as well.

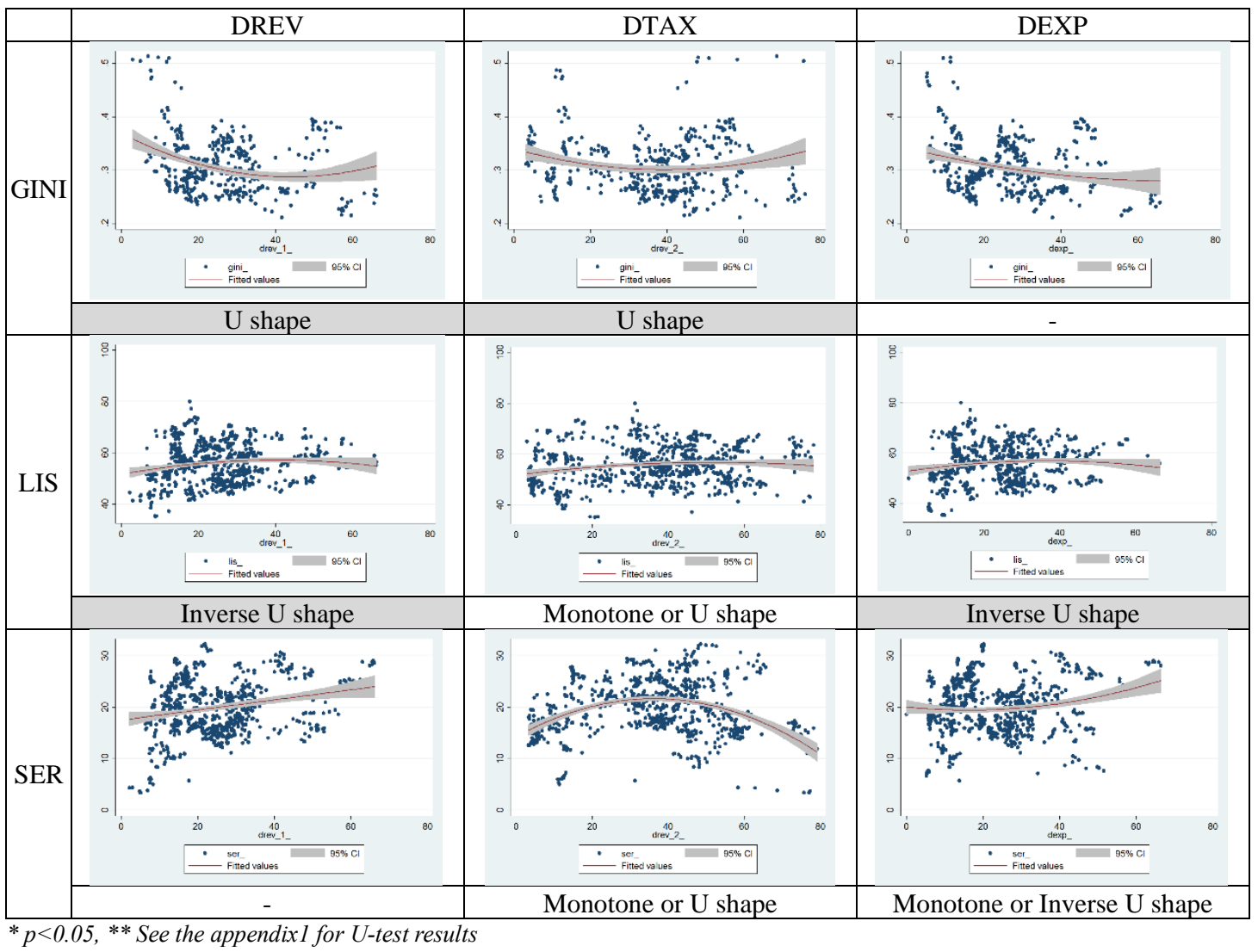

Figure 1. Fiscal decentralization-inclusive growth Laffer curve with quadratic prediction plots

Based on the above findings, this study derives the following policy implications:

First, this study found that tax decentralization by increasing the proportion of local taxes to total tax revenue of the general government can reduce inequality. It could be interpreted as decision making authority matters. Second, the relationship between fiscal decentralization and inclusive growth was changed based on specific thresholds, and it was verified through a Laffer curve. In other words, while fiscal decentralization contributes to inclusive growth in countries with low levels of institutionalization of fiscal decentralization, it has been confirmed that decentralization policy needs to be utilized in a balanced way in countries with expanded fiscal decentralization. 
As a limitation, we tried to find the data-driven evidence of fiscal decentralization policy on redistribution, however, this study utilized the OECD countries from 1995 to 2017. For stronger support of our Laffer curve impact hypothesis of fiscal decentralization policy on redistribution, expansion of data set to include underdeveloped countries is needed. In addition, we utilize three proxies to measure the level of redistribution, Gini, labor income, and social welfare expenditure share, cluster or factor analysis for more balanced measure finding is worthwhile for next step studies.

\section{References}

[1] Council of Economic Advisers and Executive Office of the President, "Economic report of the president," the Annual Report of the Council of Economic Advisers (CEA), (2016)

[2] J. Ostry and B. Andrew, "Inequality and unsustainable growth; two sides of the same coin?" IMF Staff Discussion Notes, no.11/08, (2011)

[3] J. Ostry, B. Andrew, and G. Charalambos, "Redistribution, inequality, and growth," Staff Discussion Notes, no. 14/2, IMF, (2014)

[4] Joseph E. Stiglitz, "The price of inequality: How today's divided society endangers our future," WW Norton \& Company, New York, (2013)

[5] B. Neyapti, "Fiscal decentralization and deficits: International evidence," European Journal of Political Economy, vol.26, no.2, pp.155-166, (2010) DOI: 10.1016/j.ejpoleco.2010.01.001

[6] Y. Qian and B. R. Weingast, "Federalism as a commitment to reserving market incentives," Journal of Economic perspectives, vol.11, no.4, pp.83-92, (1997) DOI: 10.1257/jep.11.4.83

[7] Rodríguez-Pose and R. Ezcurra, "Is fiscal decentralization harmful for economic growth? Evidence from the OECD countries,” Journal of Economic Geography, vol.11, no.4, pp.619-643, (2010) DOI: 10.1093/jeg/lbq025

[8] Sacchi and S. Salotti, "The effects of fiscal decentralization on household income inequality: some empirical evidence," Spatial Economic Analysis, vol.9, no.2, pp.202-222, (2014) DOI: 10.1080/17421772.2013.833343

[9] Sepulveda and J. Martinez-Vazquez, "Explaining property tax collections in developing countries: the case of Latin America," In Decentralization and reform in Latin America, Edward Elgar Publishing, (2012) DOI: $10.4337 / 9781781006269$

[10] V. Tselios, A. Rodriguez-Pose, A. Pike, J. Tomaney, and Gianpiero. Torrisi, "Income inequality, decentralization and regional development in Western Europe," Environment and Planning A, vol.44, no.6, pp.1278-1301, (2011) DOI: 10.1068/a44334

[11] R. Crook and A. S. Sverrisson, "Does decentralization contribute to poverty reduction," Changing paths: International development and the new politics of inclusion, University of Michigan Press, pp.233-259, (2003)

[12] H. Davoodi and H. Zou, "Fiscal decentralization and economic growth: a cross-country study," Journal of Urban Economics, vol.43, no.2, pp.244-257, (1998) DOI: 10.1006/juec.1997.2042

[13] J. P. Jütting, C. Kauffmann, I. McDonnell, H. Osterrieder, N. Pinaud, and L. Wegner, "Decentralization and poverty in developing countries: exploring the impact," OECD Development Centre Working, article no.236, (2004) DOI: $10.2139 / \mathrm{ssrn} .583762$

[14] J. I. Litvack, J.Ahmad, and R. M. Bird, "Rethinking Decentralization in Developing Countries," World Bank Publications, (1998) DOI: 10.1596/0-8213-4350-5

[15] V. Tanzi, "Fiscal federalism and decentralization: a review of some efficiency and macroeconomics aspects," In M. Bruno and B. Pleskovic(eds.), Annual World Bank Conference on Development Economics, Washington D.C. World Bank, (1996)

[16] J. Von Braun and U. Grote, "Does decentralization serve the poor?" in Ahmad, E. and V. Tanzi (eds), Managing Fiscal Decentralization, London, Routledge, pp.68-95, (2002) DOI: 10.4324/9780203219997.ch4

[17] T. Zhang, H.F. Zou, "Fiscal decentralization, public spending, and economic growth in China," Journal of public economics, vol.67, no.2, pp.221-240, DOI: 10.1016/S0047-2727(97)00057-1 
[18] W. Oates, "Fiscal federalism", Harcourt Brace Jovanovich, New York, (1972)

[19] R. A. Musgrave, “Theory of public finance; a study in public economy,” McGraw-Hill, New York, (1959)

[20] E. G. Aslim and B. Neyapti, "Optimal fiscal decentralization: Redistribution and welfare implications," Economic Modelling, vol.61, pp.224-234, (2017) DOI: 10.1016/j.econmod.2016.12.008

[21] J. T. Lind and H. Mehlum, "With or without U? The appropriate test for a U - shaped relationship," Oxford bulletin of economics and statistics, vol.72, no.1, pp.109-118, (2010) DOI: 10.1111/j.1468-0084.2009.00569.x 